\title{
Klasifikasi Makna Tangisan Bayi Menggunakan CNN Berdasarkan Kombinasi Fitur MFCC Dan DWT
}

\author{
Yohannes*1, Ricky Wijaya $^{2}$ \\ ${ }^{1,2}$ STMIK Global Informatika MDP; Jalan Rajawali No. 14, (0711) 376400 \\ ${ }^{1,2}$ Program Studi Teknik Informatika, STMIK Global Informatika MDP, Palembang \\ e-mail: *11yohannesmasterous@mdp.ac.id, ${ }^{2}$ rickywijaya1998@ gmail.com
}

\begin{abstract}
Abstrak
Menangis merupakan cara bayi untuk berkomunikasi. Suara tangisan tersebut dapat digunakan untuk mengidentifikasi masalah pada bayi, seperti kelaparan, kesakitan, rasa kantuk, kelelahan, rasa tidak nyaman, kedinginan atau kepanasan, dan lain-lain. Namun, tidak semua orang dapat mengenali makna tangisan bayi tersebut. Kombinasi dari fitur MFCC dan DWT digunakan pada penelitian ini sebagai fitur ekstraksi pada suara tangisan bayi. Pada penelitian ini, metode Convolutional Neural Network (CNN) digunakan untuk klasifikasi makna suara dari tangisan bayi. Dataset yang digunakan pada penelitian ini adalah dataset publik yang terdiri dari total 61 data training dan 30 data testing. Jenis tangisan bayi yang digunakan pada penelitian ini adalah lapar, lelah, rasa tidak nyaman, dan sakit perut. Berdasarkan hasil pengujian, fitur MFCC dan CNN didapatkan precision sebesar 32,76\%, recall sebesar 32,63\%, dan accuracy sebesar 73,33\%. Kombinasi fitur MFCC dan DWT (Mean, Standard Deviation, Range, Max) dan CNN didapatkan precision sebesar 50,91\%, recall sebesar 44,23\%, dan accuracy sebesar 73,33\%.
\end{abstract}

Kata kunci-Tangisan Bayi, MFCC, DWT, CNN, Klasifikasi

\begin{abstract}
Crying is a baby's way of communicating. The sound of crying can be used to identify problems in babies, such as hunger, pain, drowsiness, fatigue, discomfort, coldness or heat, and others. However, not everyone can recognize the meaning of the crying baby. The combination of MFCC and DWT features was used in this study as an extraction feature in baby crying sounds. In this study, the Convolutional Neural Network (CNN) method is used to classify the meanings of sounds from babies crying. The dataset used in this study is a public dataset consisting of a total of 61 training data and 30 testing data. The types of crying babies used in this study were hunger, fatigue, discomfort, and stomach ache. Based on the test results, the MFCC and CNN features obtained a precision of 32.76\%, a recall of 32.63\%, and an accuracy of $73.33 \%$. The combination of MFCC and DWT features (Mean, Standard Deviation, Range, Max) and CNN obtained a precision of $50.91 \%$, a recall of $44.23 \%$, and an accuracy of $73.33 \%$.
\end{abstract}

Keywords—Baby Cry, MFCC, DWT, CNN, Classification

\section{PENDAHULUAN}

$\mathrm{K}$ omunikasi adalah proses penyampaian informasi, gagasan, emosi, dan lain-lain melalui ucapan, gerakan, gambar, simbol-simbol, dll. Komunikasi dibagi menjadi tiga jenis yaitu komunikasi intrapersonal yaitu komunikasi dengan diri sendiri, komunikasi interpersonal yaitu komunikasi yang dilakukan oleh dua orang atau lebih, dan komunikasi kelompok yaitu 
komunikasi yang dilakukan oleh kelompok-kelompok [1]. Menangis adalah satu-satunya cara bayi yang baru lahir untuk berkomunikasi. Dengan menangis, bayi yang baru lahir bisa mengekspresikan fisik, emosional dan kebutuhannya. Ada beberapa alasan kenapa bayi menangis, seperti lapar, lelah, sakit perut, dan rasa tidak nyaman. Untuk memenuhi kebutuhan bayi, sangat penting bagi orang tua untuk bertindak dengan cepat. Seringkali, orang tua tidak selalu mampu memahami mengapa bayi mereka menangis. Hal ini membuat para orang tua menjadi bingung dan frustrasi karena mereka merasa tidak berdaya dalam menghadapi tangisan pada bayi yang baru lahir.

Dari permasalahan tentang tangisan bayi, ada beberapa penelitian yang terkait mengenai klasifikasi pada tangisan bayi. Beberapa penelitian tersebut adalah penelitian [2] tentang identifikasi suara tangisan bayi menggunakan metode LPC dan Euclidean Distance. Pada penelitian [3] telah menggunakan metode Moments of Distribution dan K-Nearest Neighbours untuk klasifikasi suara tangisan bayi. Identifikasi tangisan bayi juga dilakukan [4] menggunakan Learning Vector Quantization dan Mel-Frequency Cepstral Coefficients (MFCC).

Untuk mendapatkan informasi dari objek suara diperlukan proses ekstraksi. Terdapat beberapa metode ekstraksi fitur suara yang dapat digunakan, seperti Mel-Frequency Cepstral Coefficients (MFCC) dan Discrete Wavelet Tranform (DWT). MFCC merupakan proses ekstraksi ciri sinyal suara yang menghasilkan koefisien-koefisien MFCC sebagai urutan vector [5]. MFCC mampu mengambil informasi-informasi penting yang terkandung dalam sinyal, menghasilkan data seminimal mungkin tanpa menghilangkan informasi penting yang ada, dan mengadaptasi organ pendengaran manusia dalam melakukan persepsi terhadap sinyal suara. Penelitian [4] menggunakan MFCC sebagai fitur ekstraksi dan LVQ sebagai fitur klasifikasi dalam mengidentifikasi tangisan bayi. Penelitian [6] menggunakan fitur ekstraksi MFCC dan LFCC dalam mempelajari tangisan bayi. MFCC juga digunakan [7] dalam melakukan identifikasi pada tangisan bayi. Pada penelitian [8] menggunakan MFCC dan LDA sebagai fitur ekstraksi dalam pengenalan bahasa Marathi.

Fitur ekstraksi DWT adalah transformasi wavelet yang mampu menangkap representasi waktu dan skala dari sebuah sinyal menggunakan teknik pem-filter-an digital dan operasi subsampling [9]. Transformasi wavelet mempunyai fungsi untuk menghilangkan suara bising saat proses pengolahan sinyal [10]. Penelitian [11] mengurangi suara bising pada sinyal bicara menggunakan DWT. DWT juga pernah dipakai pada penelitian [12] dalam melakukan analisis audio. Selain itu, pada penelitian [10] menggunakan DWT dan Singular Vector Decomposition dalam mengurangi suara bising.

Kombinasi dari fitur ekstraksi MFCC dan DWT dalam pengolahan sinyal pernah dipakai pada penelitian-penelitian sebelumnya, seperti yang dilakukan [13] dalam menggunakan kombinasi fitur ekstraksi MFCC dan DWT dalam pengenalan ucapan untuk sistem keamanan bank dan ATM. Penelitian [14] menggunakan kombinasi MFCC sebagai fitur ekstraksi dan DWT untuk mengurangi suara bising untuk sistem pengenalan ucapan. Kombinasi fitur MFCC dan DWT juga dilakukan oleh penelitian [15] dalam pengenalan bahasa Marathi.

Setelah melakukan ekstraksi fitur, diperlukan juga metode klasifikasi. CNN adalah salah satu model pembelajaran deep learning yang populer dan banyak diterapkan di bidang penelitian seperti pengenalan objek, pengenalan wajah, pengenalan tulisan tangan, dan pengenalan suara. Menurut [16] CNN merupakan salah satu metode deep learning yang mampu mempelajari representasi data dengan mengkombinasikan teknik local receptive inputs, weight sharing dan convolutions untuk mengatasi masalah invariance dilemma.

Terdapat beberapa penelitian yang menerapkan klasifikasi suara, yaitu oleh [17] menggunakan CNN dan regresi logistik untuk mengidentifikasi tangisan bayi. CNN juga digunakan oleh [18] untuk melakukan klasifikasi suara. Pada penelitian yang dilakukan oleh [19] dilakukan klasifikasi suara di sekitar dengan menggunakan CNN dan Tensor Deep Stacking 
Network sebagai klasifikasi. CNN sebagai metode klasifikasi dipakai oleh [20] dalam melakukan klasifikasi suara pada hewan.

Berdasarkan penelitian terdahulu, fitur MFCC dan DWT berpotensi untuk melakukan kombinasi fitur, serta menerapkan CNN untuk klasifikasi makna tangisan bayi. Objek penelitian yang digunakan adalah suara tangisan bayi dari dataset Donateacry.

\section{METODE PENELITIAN}

Tahapan metode penelitian ini dimulai dari identifikasi masalah, studi literatur, pengumpulan data, perancangan sistem, implementasi, dan evaluasi.

\subsection{Identifikasi Masalah}

Pada tahapan ini yaitu menemukan permasalahan sesuai bidang ilmu, dalam hal ini adalah klasifikasi makna suara tangisan bayi.

\subsection{Studi Literatur}

Pada tahap ini dilakukan literatur, pencarian jurnal, buku dan hasil penelitian yang berkaitan dengan topik penelitian ini, yaitu Mel-Frequency Cepstral Coefficients (MFCC), Discrete Wavelet Transform (DWT) dan Convolutional Neural Network (CNN).

\subsubsection{Mel-Frequency Cepstral Coefficients (MFCC)}

Mel-Frequency Cepstral Coefficients (MFCC) merupakan salah satu fitur populer teknik ekstraksi untuk sinyal ucapan [21]. MFCC dapat meniru tingkah laku pendengaran manusia yang tidak dapat menerima frekuensi diatas $1 \mathrm{Khz}$. MFCC didasarkan pada variasi bandwidth telinga manusia yang kritis dengan frekuensi. MFCC memiliki dua jenis filter yang bekerja secara linier pada frekuensi rendah di bawah $1.000 \mathrm{~Hz}$ dan logaritmik diatas $1.000 \mathrm{~Hz}$. MFCC mempunyai keunggulan dapat menganalisis kelompok suara berdasarkan pola sinyal suara masukan, memberikan fitur dengan ukuran data yang kecil berupa vektor dengan tidak meniadakan karakteristik dari suara asli, dan mengadaptasi organ pendengaran manusia dalam melakukan persepsi terhadap sinyal suara. Sinyal suara yang diekstraksi menggunakan MFCC akan menjadi seubah fitur vektor. Proses MFCC dimulai dari pre-emphasis, framing, windowing, fast fourier transform, mel frequency warping, discrete cosine transform, hingga cepstral filtering [22].

\section{Pre-emphasis}

Pada langkah ini sinyal akan dipertahankan pada frekuensi-frekuensi tinggi pada sebuah spektrum yang umumnya tereduksi saat proses produksi suara [23]. Pada tahap ini, berkas audio yang telah dibaca sebagai data sinyal frekuensi dalam tipe data array sepanjang detik akan ditransformasi menjadi sinyal frekuensi baru pada Persamaan (1).

Keterangan:

$$
y_{n}=x_{n}-\alpha \times x_{n-1}, 0,9 \leq \alpha \leq 1 \text { (1) }
$$

$y_{n}=$ sinyal hasil pre-emphasis

$x_{n}=$ sinyal sebelum pre-emphasis

2. Framing

Pada langkah ini terjadi proses segmentasi sampel suara yang diperoleh ke dalam frame kecil dengan durasi waktu sekitar 20-40 milidetik. Proses framing ini akan dilakukan secara terus-menerus sampai seluruh sinyal dapat diproses. Pada umumnya, proses ini dilakukan secara overlapping pada setiap frame-nya. Panjangnya overlap yang umum digunakan ialah $30 \%$ hingga $50 \%$ dari panjang frame [23]. Dengan adanya overlapping, hilangnya karakteristik suara pada perbatasan perpotongan setiap frame dapat dihindari. 
3. Windowing

Pada langkah ini efek aliasing pada sinyal yang diproses setelah proses framing akan dikurangi [23]. Aliasing adalah sinyal baru yang frekuensinya berbeda dengan frekuensi sinyal aslinya akibat dari rendahnya sampling rate atau proses framing yang menyebabkan sinyal terputus. Proses Windowing dapat dihitung dengan Persamaan (2).

Keterangan:

$$
y_{n}=x_{n} \times w_{n}, 0 \leq n \leq N-1
$$

$N=$ jumlah sampel pada setiap frame

$y_{n}=$ nilai sinyal hasil windowing

$x_{n}=$ nilai dari frame sinyal ke- $n$

$w_{n}=$ Fungsi window

Jenis window yang digunakan adalah Hamming Window yang dapat dihitung dengan Persamaan (3).

4. Fast Fourier Transform

$$
w_{n}=0,54-0,46 \cos \frac{2 \pi n}{N-1}, 0 \leq n \leq N-1
$$

Fast Fourier Transform (FFT) digunakan mengubah tiap frame frekuensi pada sample dari domain waktu menjadi domain frekuensi dan untuk menganalisa spektogram berdasarkan sinyal yang dimasukkan [23]. Pada tahap ini, sinyal frekuensi dari proses windowing akan diproses dengan Persamaan (4).

Keterangan:

$$
x_{k}=\sum_{n=0}^{N-1} x_{n} \times e^{\frac{-2 \pi k n}{N}}, n=0 \leq n \leq N-1
$$

$x_{k}=$ jumlah frekuensi pada sinyal

$k=$ frekuensi audio sebelum FFT

$x_{n}=$ nilai sinyal pada waktu ke- $n$

$N=$ jumlah waktu pada sampel

5. Mel Frequency Warping

Mel Frequency Warping dilakukan untuk menghasilkan magnitude spectrum yang cocok dan memperkecil ukuran fitur terkait. Mel Frequency Warping dilakukan dengan menerapkan filterbank untuk mengetahui ukuran energi frequency band tertentu dalam sinyal suara. Pada tahap Mel Frequency Warping, sinyal frekuensi yang telah diproses pada tahap Fast Fourier Transform akan dirubah ke dalam frekuensi Mel dengan Persamaan (5).

Keterangan:

$$
\operatorname{Mel}(f)=2595 \log _{10}\left(1+\frac{f}{700}\right)
$$

$\mathrm{f}=$ frekuensi sinyal

6. Discrete Cosine Transform

Discrete Cosine Transform merupakan proses terakhir dari proses MFCC yang digunakan untuk mengonversi mel spectrum menjadi spektral local [24]. Hasil dari konversi ini disebut sebagai Mel-Frequency Cepstrum Coefficient yang berbentuk deretan vektor akustik. Pada tahap ini, frekuensi Mel ditransformasi dengan Persamaan (6).

Keterangan:

$$
C_{m}=\sum_{k=1}^{k}\left(\log S_{k}\right) \cos \left[m\left(k-\frac{1}{2}\right) \frac{\pi}{k}\right], m=1,2, \ldots, K
$$

Sk = keluaran dari Mel Frequency Warping

$\mathrm{K}=$ jumlah koefisien dari Mel Scale Cepstral Coefficients

7. Cepstral Filtering

Cepstral Filtering digunakan untuk memperhalus hasil dari seluruh proses MFCC agar lebih hasilnya lebih baik saat digunakan pada pattern matching. Cepstral Liftering 
diimplementasikan pada hasil Discrete Cosine Transform berupa cepstral features dengan menggunakan fungsi window pada Persamaan (7).

$$
W_{n}=1+\frac{L}{2} \sin \left[\frac{\pi n}{L}\right]
$$

Keterangan:

$\mathrm{L}=$ jumlah cepstral coefficients dan $\mathrm{n}$ adalah index dari cepstral coefficients

\subsubsection{Discrete Wavelet Transform (DWT)}

Transformasi wavelet adalah transformasi matematis yang berfungsi untuk menghilangkan suara bising pada proses pengolahan sinyal. Transformasi wavelet dapat memberikan informasi waktu dan frekuensi secara bersamaan, karena memberikan representasi frekuensi waktu dari sinyal [25]. DWT menganalisis sinyal pada pita frekuensi berbeda dengan resolusi berbeda melalui dekomposisi sinyal menjadi informasi yang detail. Wavelet didapatkan menggunakan low pass filter dan high pass filter. Proses dekomposisi sebuah sinyal menjadi pita frekuensi yang berbeda diperoleh melalui succesive high pass filtering dan low pass filtering dari sinyal domain waktu. Transformasi Discrete Wavelet Tranform dapat dilihat pada Persamaan (8).

Keterangan:

$$
W(j, k)=\sum_{j} \sum_{k} x(k) 2^{\frac{-j}{2}} \psi\left(2^{-j} n-k\right)
$$

$\Psi(\mathrm{t})=$ fungsi analisis dasar yang disebut mother wavelet .

Teknik filter ditentukan pada Persamaan (9) dan (10).

$$
\begin{aligned}
& Y \text { high }[K]=\sum X[n] g[2 k-1] \\
& Y \text { low }[k]=\sum X[n] h[2 k-1]
\end{aligned}
$$

Di mana, Y high $[\mathrm{K}]$ dan Y low $[\mathrm{k}]$ adalah output dari filter high pass dan filter low pass setelah operasi subsampling dengan 2. Sinyal ucapan akan didekomposisi dalam sub band dengan menggunakan DWT dengan 4 iterasi atau level. Energi rata-rata dihitung pada setiap sub band. Sinyal asli dapat diwakili oleh jumlah koefisien terperinci di setiap sub band, yaitu cD4, cD3, cD2, cD1. Vektor fitur ini diperoleh dari koefisien terperinci yang menerapkan nilai statistik seperti rata-rata, standar deviasi, dan sebagainya.

\subsubsection{Convolutional Neural Network (CNN)}

Convolutional Neural Network (CNN) adalah salah satu model pembelajaran deep learning yang populer yang telah banyak diterapkan di bidang penelitian seperti pengenalan objek, pengenalan wajah, pengenalan tulisan tangan, dan pengenalan suara [26]. Secara umum, CNN terdiri atas satu lapis input layer, satu lapis output layer, dan beberapa lapis hidden layer. Hidden layer umumnya berisi convolutional layer, pooling layer, Rectified Linear Units layer, dan fully connected layer [27].

1. Convolutional Layer

Lapis konvolusional (convolutional layer) merupakan blok bangunan inti CNN, di mana sebagian besar komputasi dilakukan. Convolution layer dalam arsitektur CNN umumnya menggunakan lebih dari satu filter. CNN umumnya menggunakan lebar langkah atau stride $=1$ dengan zero padding yang dapat dilihat pada Persamaan (11).

$$
P=\frac{(F-1)}{2},
$$

di mana $\mathrm{P}$ adalah ukuran padding dan $\mathrm{F}$ adalah ukuran bidang reseptif atau tingkat spasial yang sama dengan ukuran filter.

Ukuran input layer dapat dinyatakan pada Persamaan (12).

$$
w_{1} x h_{1} x d_{1}
$$

di mana $w_{1}$ dan $h_{1}$ adalah lebar dan tinggi, sedangkan $d_{1}$ adalah jumlah kanal (dalam CNN disebut depth atau kedalaman). CNN memiliki empat hyperparameters (parameter yang harus ditentukan oleh user), yaitu jumlah filter $K$, ukuran bidang reseptif atau spatial 
extent (tingkat spasial) F, lebar langkah atau stride $S$, dan zero padding $\mathrm{P}$. Volume keluaran (output) dapat dihitung dengan Persamaan (13).

$$
w_{2} \times h_{2} \times d_{2} \text {, }
$$

dimana $w_{2}, h_{2}, d_{2}$ dapat dihitung dengan Persamaan (14), (15), dan (16).

$$
\begin{aligned}
& w_{2}=\frac{\left(w_{1}-F+2 P\right)}{S}+1, \\
& h_{2}=\frac{\left(h_{1}-F+2 P\right)}{S}+1, \\
& d_{2}=K
\end{aligned}
$$

CNN umumnya didesain untuk tidak menurunkan ukuran data terlalu cepat karena dapat membuat performa CNN menurun, bahkan tidak mampu dalam menjalankan tugasnya. Apabila CNN menggunakan konvolusi 1x1, maka tujuannya untuk mereduksi kedalaman data, sedangkan lebar dan tinggi tetap dipertahankan.

2. Pooling Layer

Pooling layer berfungsi menjaga ukuran data ketika convolution, yaitu dengan melakukan downsampling (pereduksian sampel). Pooling dapat merepresentasikan data menjadi lebih kecil, mudah dikelola, dan mudah mengontrol overfitting. Proses pooling yang umum digunakan adalah max pooling yaitu memilih nilai maksimum dalam suatu area tertentu. Proses pooling lainnya yaitu average pooling yaitu menghitung nilai rata-rata dalam suatu area.

3. Rectified Linear Units Layer

Rectified Linear Units Layer mengaplikasikan fungsi aktivasi $f(x)=\max (0, x)$ yang dapat meningkatkan sifat nonlinearitas fungsi keputusan dan jaringan secara menyeluruh yang tidak mempengaruhi bidang-bidang reseptif pada convolution layer. Fungsi lain untuk meningkatkan nonlinearitas, seperti tangen hiperbolik $f(x)=\tanh (x)$, $f(x)=|\tanh (x)|$, atau $f(x)=\left(1+e^{-x}\right)^{-1}$.

4. Fully Connected Layer

Pada lapisan yang terhubungan secara penuh (fully connected layer), setiap neuron memiliki koneksi penuh ke semua aktivasi dalam lapisan sebelumnya. Hal ini sama dengan yang ada pada MLP. Komponen ini digunakan untuk baik membuat representasi input yang lebih abstrak dengan proses lebih lanjut fitur atau mengklasifikasikan input berdasarkan fitur yang diekstraksi dengan sebelumnya lapisan.

\subsection{Pengumpulan Data}

Pada tahapan ini dilakukan pengumpulan audio suara tangisan bayi yang akan diekstraksi menggunakan kombinasi MFCC dan DWT serta klasifikasi makna menggunakan CNN. Dataset yang digunakan yaitu suara tangisan bayi dengan menggunakan dataset publik Donateacry (https://github.com/gveres/donateacry-corpus) dengan durasi 6 sampai 8 detik dengan bitrate audio 128 kbps.

\subsection{Perancangan Sistem}

Pada tahapan ini dilakukan perancangan penelitian dan sistem yang dibutuhkan untuk melakukan penelitian ini, yaitu kombinasi fitur MFCC dan DWT. Ada beberapa tahapan yang dilakukan. Tahapan tersebut, yaitu membagi dataset menjadi data training dan data testing. Data training yang telah dikumpulkan dari dataset akan diektraksi menggunakan MFCC dan DWT yang dimana hasil ekstraksi dari MFCC akan dikombinasikan dengan hasil ekstraksi dari DWT. Fitur akhir hasil ekstraksi akan disimpan pada sistem. Sama seperti data training, data testing juga diperlakukan sama. Data testing diekstraksi menggunakan MFCC dan DWT yang dimana hasil ekstraksi dari MFCC akan dikombinasikan dengan hasil ekstraksi dari DWT. Fitur akhir 
hasil ekstraksi akan disimpan pada sistem. Model untuk proses klasifikasi diperoleh dari hasil proses training dan testing. Metode klasifikasi yang digunakan yaitu CNN. Secara keseluruhan, metode yang digunakan dapat dilihat pada Gambar 1.

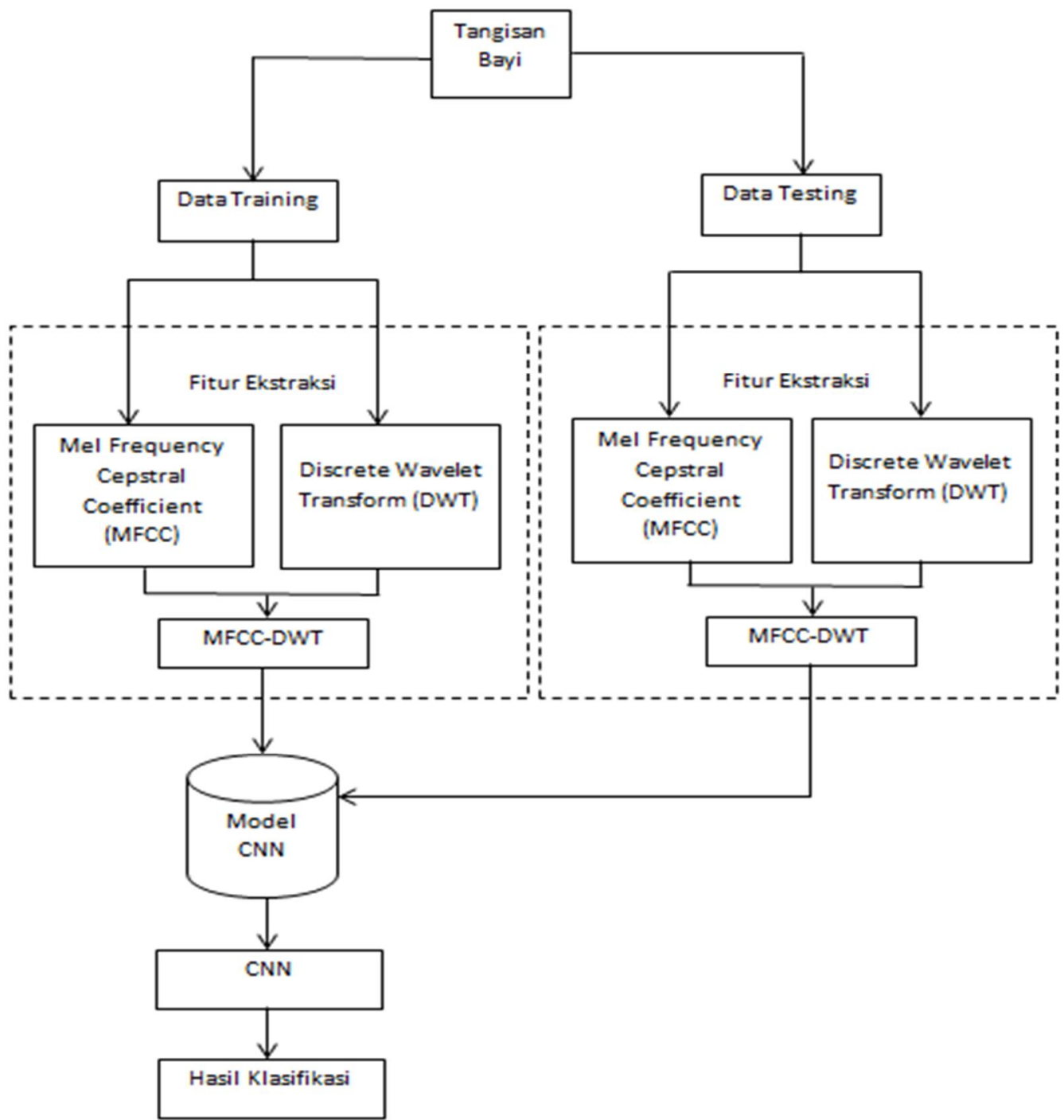

Gambar 1. Perancangan Sistem

\subsection{Implementasi}

Setelah melakukan proses perancangan sistem dilanjutkan menerapkan perancangan kedalam bentuk interface. Pada tahapan ini melakukan implementasi terhadap rancangan yang telah dibuat ke dalam bentuk program dalam bahasa pemrograman. Hasil vektor fitur pada MFCC dan DWT akan di-reshape ke ukuran input layer yang terdapat pada CNN. Pengujian menggunakan ukuran input sesuai fitur dengan 13 layer CNN. Pengujian menggunakan 3 convolutional layers dengan filter size [2 2 [ d dan stride 1 dengan fungsi aktivasi ReLU. Pengujian menggunakan 3 max pooling layers dan stride 2. Pengujian menggunakan 2 fully connected layers dan softmax. Layer pengujian dapat dilihat pada Gambar 2. 


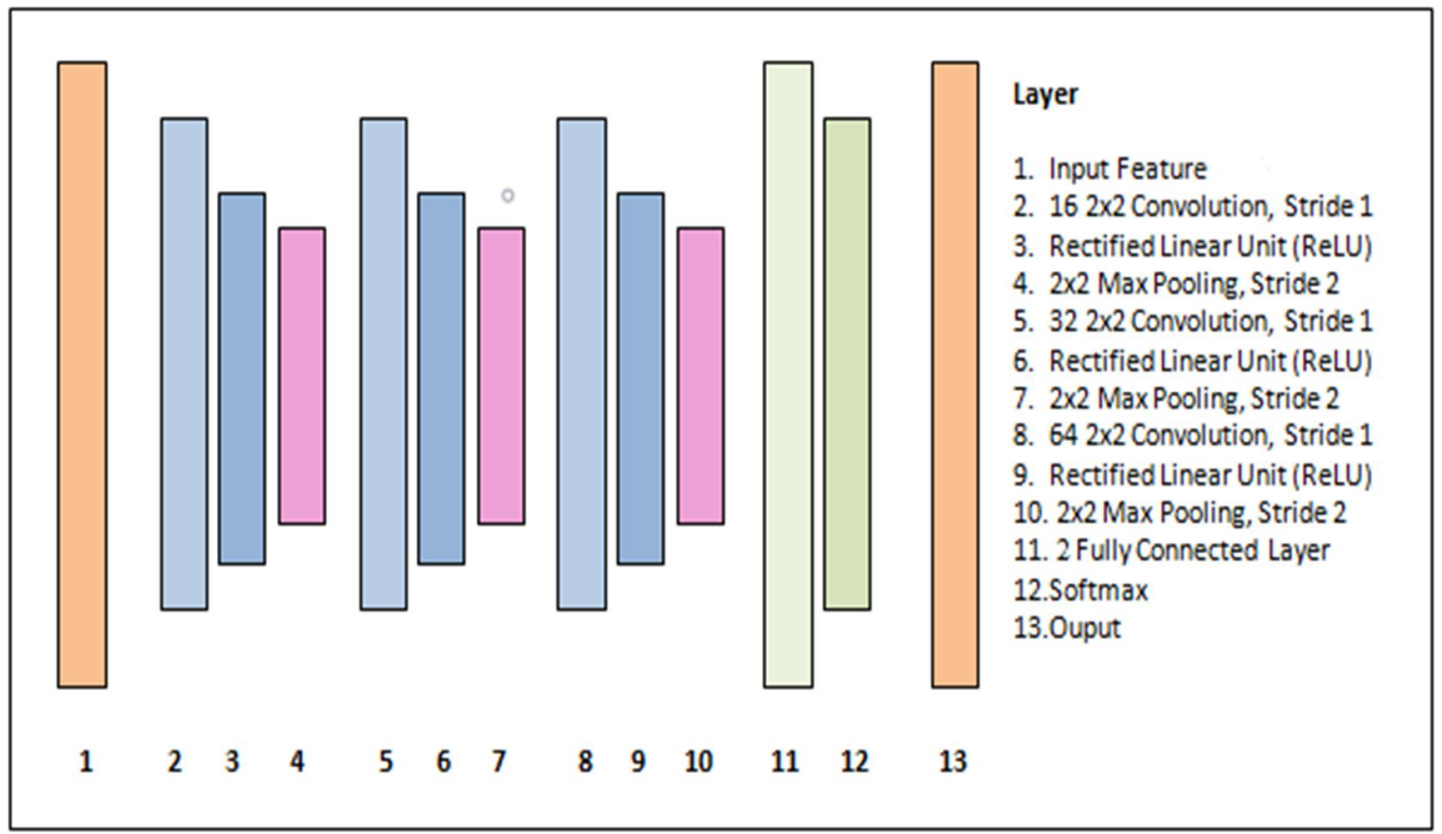

Gambar 2. Struktur Layer pada CNN pada kombinasi fitur MFCC-DWT

\subsection{Evaluasi}

Setelah melakukan proses implementasi dilanjutkan dengan proses pengujian pada suara training dan suara testing untuk 1 jenis tangisan bayi dimana pada pembagiannya $67 \%$ training dan $33 \%$ testing. Selanjutnya, hasil klasifikasi dihitung untuk mendapatkan tingkat keberhasilan dari metode yang digunakan, dengan menggunakan metode confusion matrix yang dimana akan menghitung nilai precision, recall, dan accuracy secara berturut-turut pada Persamaan (17), (18), dan (19).

Keterangan:

$$
\begin{aligned}
& \text { Precision }=\frac{T P}{T P+F P} \\
& \text { Recall }=\frac{T P}{T P+F N} \\
& \text { Accuracy }=\frac{T P+T N}{T P+T N+F P+F N}
\end{aligned}
$$

$\mathrm{TP}=$ Jumlah data positif suara tangisan bayi yang terklasifikasi dengan benar oleh sistem.

$\mathrm{TN}=$ Jumlah data negatif suara tangisan bayi yang terklasifikasi dengan benar oleh sistem.

$\mathrm{FP}=$ Jumlah data positif tangisan bayi namun terklasifikasi salah oleh sistem.

$\mathrm{FN}=$ Jumlah data negatif tangisan namun terklasifikasi benar oleh sistem.

\section{HASIL DAN PEMBAHASAN}

Pada bagian ini dijelaskan mengenai implementasi proses penelitian untuk mendapatkan hasil yang dibutuhkan pada penelitian, yaitu MFCC dan DWT untuk ekstraksi fitur dan CNN untuk proses klasifikasi.

\subsection{Implementasi MFCC}

Pada tahap ini, hasil training dan testing data yang telah dilakukan menggunakan 61 data train dan 30 data test, suara tangisan bayi akan diekstrak oleh MFCC dan hasilnya akan 
dinormalisasi dengan mencari nilai mean pada setiap kolom yang akan menghasilkan fitur vektor berukuran $1 \times 14$.

\subsection{Implementasi DWT}

Klasifikasi CNN ini bertujuan untuk membedakan 4 jenis tangisan bayi yang dibedakan dari data fitur yang didapat dari proses ekstraksi MFCC dan DWT. Klasifikasi CNN didapat dari proses training. Pada proses training akan diambil data tangisan bermakna lapar sebanyak 16 data, data tangisan bermakna lelah sebanyak 16 data, data tangisan bermakna rasa tidak nyaman sebanyak 18 data, dan data tangisan bermakna sakit perut sebanyak 11 data. Pada proses testing akan diambil data tangisan bermakna lapar sebanyak 8 data, data tangisan bermakna lelah sebanyak 8 data, data tangisan bermakna rasa tidak nyaman sebanyak 9 data, data tangisan bermakna sakit perut sebanyak 5 data.

\subsection{Implementasi CNN}

Pada tahap ini, sinyal suara akan didekomposisi oleh DWT sebanyak 4 level. Energi rata-rata dihitung untuk setiap sub band. Sinyal asli diwakili oleh jumlah koefisien dari setiap sub band. Fitur vektor ini diperoleh dari detail koefisien yang menerapkan nilai statistik seperti mean, standard deviation, range, dan maximum dari setiap sub band. Setelah proses ekstraksi fitur akan didapatkan dua fitur vector, yaitu fitur vektor MFCC dan fitur vektor DWT. Fitur vektor akhir diperoleh dengan menambah fitur vektor MFCC dan fitur vektor DWT.

\subsection{Hasil Pengujian}

Hasil pengujian yang didapat dari kombinasi fitur MFCC-DWT menggunakan CNN berupa precision, recall, dan accuracy yang berasal dari perhitungan rata-rata, pengujian tersebut dapat dilihat pada Tabel 1 .

Tabel 1. Hasil Klasifikasi Menggunakan Kombinasi Fitur MFCC-DWT Dengan CNN

\begin{tabular}{|c|l|c|c|c|}
\hline No & \multicolumn{1}{|c|}{ Kombinasi Fitur } & Precision & Recall & Accuracy \\
\hline 1 & MFCC & $\mathbf{3 2 , 7 6 \%}$ & $\mathbf{3 2 , 6 3 \%}$ & $\mathbf{6 8 , 3 3 \%}$ \\
\hline 2 & MFCC-DWT (Mean) & $25,41 \%$ & $23,95 \%$ & $63,33 \%$ \\
\hline 3 & MFCC-DWT (Standard Deviation) & $29,56 \%$ & 30,20 & $66,67 \%$ \\
\hline 4 & MFCC-DWT (Range) & $42,61 \%$ & $32,98 \%$ & $68,33 \%$ \\
\hline 5 & MFCC-DWT (Max) & $\mathbf{2 2 , 9 1 \%}$ & $\mathbf{2 3 , 9 5 \%}$ & $\mathbf{6 3 , 3 3 \%}$ \\
\hline 6 & MFCC-DWT (Mean, Standard Deviation) & $32,63 \%$ & $35,76 \%$ & $70 \%$ \\
\hline 7 & MFCC-DWT (Mean, Range) & $26,54 \%$ & $30,20 \%$ & $66,67 \%$ \\
\hline 8 & MFCC-DWT (Mean, Max) & $29,44 \%$ & $27,43 \%$ & $65 \%$ \\
\hline 9 & MFCC-DWT (Standard Deviation, Range) & $28,90 \%$ & $23,95 \%$ & $63,33 \%$ \\
\hline 10 & MFCC-DWT (Standard Deviation, Max) & $27,53 \%$ & $29,86 \%$ & $66,67 \%$ \\
\hline 11 & MFCC-DWT (Range, Max) & $32,85 \%$ & $29,51 \%$ & $66,67 \%$ \\
\hline 12 & $\begin{array}{l}\text { MFCC-DWT (Mean, Standard Deviation, } \\
\text { Range) }\end{array}$ & $29,44 \%$ & $32,98 \%$ & $68,33 \%$ \\
\hline 13 & $\begin{array}{l}\text { MFCC-DWT (Mean, Standard Deviation, } \\
\text { Max) }\end{array}$ & $30,20 \%$ & $33,97 \%$ & $68,96 \%$ \\
\hline 14 & MFCC-DWT (Mean, Range, Max) & $25,16 \%$ & $23,95 \%$ & $63,33 \%$ \\
\hline 15 & $\begin{array}{l}\text { MFCC-DWT (Standard Deviation, Range, } \\
\text { Max) }\end{array}$ & $24,24 \%$ & $27,43 \%$ & $65 \%$ \\
\hline 16 & $\begin{array}{l}\text { MFCC-DWT (Mean, Standard Deviation, } \\
\text { Range, Max) }\end{array}$ & $\mathbf{5 0 , 9 1 \%}$ & $\mathbf{4 4 , 2 3 \%}$ & $\mathbf{7 3 , 3 3 \%}$ \\
\hline
\end{tabular}




\section{KESIMPULAN}

Kesimpulan dari hasil penelitian mengenai kombinasi fitur MFCC dan DWT untuk klasifikasi makna tangisan bayi menggunakan $\mathrm{CNN}$ adalah sebagai berikut:

1. Performa CNN dengan fitur MFCC dalam mengenali jenis tangisan bayi mendapatkan nilai rata-rata untuk precision sebesar 32,76\%, recall sebesar 32,63\%, dan accuracy sebesar $68,33 \%$.

2. Performa CNN dengan kombinasi fitur MFCC-DWT (Mean, Standard Deviation, Range, Max) mendapat nilai terbaik dalam mengenali jenis tangisan bayi mendapatkan nilai rata-rata untuk precision sebesar 50,91\%, recall sebesar 44,23\%, dan accuracy sebesar 73,33\%.

3. Performa CNN dengan kombinasi fitur MFCC-DWT (Max) mendapat nilai terburuk untuk mengenali jenis tangisan bayi mendapatkan nilai rata-rata untuk precision sebesar $22,91 \%$, recall sebesar $23,95 \%$, dan accuracy sebesar $63,33 \%$.

\section{SARAN}

Saran yang dapat menjadi rekomendasi untuk penelitian selanjutnya adalah sebagai berikut:

1. Menggunakan kombinasi metode selain DWT terhadap fitur ekstraksi MFCC.

2. Menggunakan metode fitur klasifikasi selain metode $\mathrm{CNN}$ atau dapat menggunakan varian kombinasi metode terhadap CNN.

\section{DAFTAR PUSTAKA}

[1] O. U. Effendy. 2007, Ilmu Komunikasi Teori dan Praktek. Remaja Rosdakarya, Bandung.

[2] I. A. Dewi, A. Zulkarnain, and A. A. Lestari. 2018, "Identifikasi Suara Tangisan Bayi Menggunakan Metode LPC dan Euclidean Distance," ELKOMIKA J. Tek. Energi Elektr. Tek. Telekomun. Tek. Elektron., Vol. 6, No. 1, p. 153, doi: 10.26760/elkomika.v6i1.153.

[3] A. S. Prayogi, M. Rizqi, and T. M. Fahrudin. 2019, "Klasifikasi Suara Tangisan Bayi Berdasarkan Prosodic Features Menggunakan Metode Moments of Distribution dan KNearest Neighbours," Teknika, Vol. 8, No. 2, pp. 119-125, doi: 10.34148/teknika.v8i2.206.

[4] M. I. Choudry. 2016, “Rancang Bangun Sistem Identifikasi Tangis Bayi Menggunakan Learning Vector Quantization dan Mel Frequency Cepstral Coefficients," Universitas Multimedia Nusantara.

[5] Z. Razak, N. J. Ibrahim, E. M. Tamil, M. Y. I. Idris, and M. Y. @ Z. B. M. Yusoff. 2008, "Quranic Verse Recitation Feature Extraction Using Mel-Frequency Cepstral Coefficient (MFCC),” 4th Int. Colloq. Signal Process. its Appl., No. March, pp. 978-983, doi: 10.13140/2.1.1091.9368.

[6] S. P. Dewi, A. L. Prasasti, and B. Irawan. 2019, "The Study of Baby Crying Analysis Using MFCC and LFCC in Different Classification Methods," Proc. - 2019 IEEE Int. Conf. Signals Syst. ICSigSys 2019, pp. 18-23, doi: 10.1109/ICSIGSYS.2019.8811070. 
[7] M. D. Renanti, 2013, "Identifikasi Jenis Tangis Bayi Menggunakan Codebook Untuk Pengenal Pola dan MFCC Untuk Ekstraksi Ciri,” Institut Pertanian Bogor.

[8] S. Gaikwad, B. Gawali, P. Yannawar, and S. Mehrotra. 2011, "Feature Extraction Using Fusion MFCC for Continuous Marathi Speech Recognition,” Proc. - 2011 Annu. IEEE India Conf. Eng. Sustain. Solut. INDICON-2011, doi: 10.1109/INDCON.2011.6139372.

[9] C. Reza. 2013, "Teknik Proteksi Diferensial pada Transformator Daya Tiga Fasa Menggunakan Transformasi Wavelet," Universitas Pendidikan Indonesia.

[10] R. Patil. 2015, "Noise Reduction Using Wavelet Transform and Singular Vector Decomposition," Procedia Comput. Sci., Vol. 54, pp. 849-853, doi: 10.1016/j.procs.2015.06.099.

[11] R. Aggarwal, J. Karan Singh, V. Kumar Gupta, S. Rathore, M. Tiwari, and A. Khare, 2011, "Noise Reduction of Speech Signal Using Wavelet Transform with Modified Universal Threshold," Int. J. Comput. Appl., Vol. 20, No. 5, pp. 14-19, doi: 10.5120/2431-3269.

[12] G. Tzanetakis, G. Essl, and P. Cook, 2001, "Audio Analysis Using The Discrete Wavelet Transform,” Proc. WSES Int. Conf. Acoust. Music Theory Appl. (AMTA 2001).

[13] S. T. Saste and S. M. Jagdale, 2017 "Emotion Recognition from Speech Using MFCC and DWT for Security System," Proc. Int. Conf. Electron. Commun. Aerosp. Technol. ICECA 2017, pp. 701-704, doi: 10.1109/ICECA.2017.8203631.

[14] R. Hidayat, A. Bejo, S. Sumaryono, and A. Winursito. 2018, "Denoising Speech for MFCC Feature Extraction Using Wavelet Transformation in Speech Recognition System," 2018 10th Int. Conf. Inf. Technol. Electr. Eng., doi: 10.1109/ICITEED.2018.8534807.

[15] D. D. Joshi and M. B. Zalte. 2013, "Recognition of Emotion from Marathi Speech Using MFCC and DWT Algorithms," Int. J. Adv. Comput. Eng. Commun. Technol., Vol. 2, No. 2, pp. 59-63.

[16] Y. Gultom, R. J. Masikome, and A. M. Arymurthy. 2018, "Batik Classification using Deep Convolutional Network Transfer Learning," J. Ilmu Komput. dan Inf., vol. 11, no. 2, pp. 59-66, doi: 10.21609/jiki.v11i2.507.

[17] Y. Lavner, R. Cohen, D. Ruinskiy, and H. Ijzerman. 2016, "Baby Cry Detection in Domestic Environment using Deep Learning,” 2016 IEEE Int. Conf. Sci. Electr. Eng. ICSEE 2016, doi: 10.1109/ICSEE.2016.7806117.

[18] K. Jaiswal and D. K. Patel. 2018, "Sound Classification Using Convolutional Neural Networks," Proc. - 7th IEEE Int. Conf. Cloud Comput. Emerg. Mark. CCEM 2018, pp. 81-84, doi: 10.1109/CCEM.2018.00021.

[19] A. Khamparia, D. Gupta, N. G. Nhu, A. Khanna, B. Pandey, and P. Tiwari. 2019, "Sound Classification Using Convolutional Neural Network and Tensor Deep Stacking Network," IEEE, Vol. 7, pp. 7717-7727, doi: 10.1109/ACCESS.2018.2888882. 
[20] E. Sasmaz and F. B. Tek. 2018, “Animal Sound Classification Using A Convolutional Neural Network,” UBMK 2018 - 3rd Int. Conf. Comput. Sci. Eng., pp. 625-629, doi: 10.1109/UBMK.2018.8566449.

[21] L. Muda, M. Begam, and I. Elamvazuthi. 2010, "Voice Recognition Algorithms using Mel Frequency Cepstral Coefficient (MFCC) and Dynamic Time Warping (DTW) Techniques," Vol. 2, No. 3, pp. 138-143,

[22] W. S. Limantoro, C. Fatichah, and U. L. Yuhana, 2016, "Rancang Bangun Aplikasi Pendeteksi Suara Tangisan Bayi," J. Tek. ITS, Vol. 5, No. 2, doi: 10.12962/j23373539.v5i2.17817.

[23] D. Putra and A. Resmawan, 2011. "Verifikasi Biometrika Suara Menggunakan Metode MFCC dan DTW," Lontar Komput., Vol. 2, No. 1, pp. 8-21.

[24] R. Jang, 2005, Audio Signal Processing and Recognition, National Taiwan University.

[25] E. S. Gopi, R. Lakshmi, N. Ramya, and S. M. S. Farzana. 2004, "Music Indexing Using Independent Component Analysis with Pseudo-generated Sources," Indep. Compon. Anal. Blind Signal Sep. Fifth Int. Conf. ICA 2004, Granada, Spain, Sept. 22-24, Proc., pp. 1237-1244, 2004, doi: 10.1007/978-3-540-30110-3_156.

[26] R. Zatarain-Cabada, M. L. Barron-Estrada, F. Gonzales-Hernandez, and H. RodriguezRangel. 2018, "Emotion Recognition Using a Convolutional Neural Network," MICAI 2017 Adv. Comput. Intell., Vol. 10633, pp. 208-219, doi: 10.1007/978-3-030-02840-4.

[27] I. Vasilev, D. Slater, G. Spacagna, P. Roelants, and V. Zocca. 2019, Python Deep Learning, Second Edi. Packt Publishing. 